\title{
胆囊癌に対する超音波穿刺術の意義
}

\author{
千葉大学医学部第 2 外科 \\ 渡辺 義二 植松 貞夫 竜崇正 \\ 古川 隆男菊池俊之尾崎 正彦 \\ 小出 義雄 小高 道雄佐藤 博
}

\section{CLINICAL SIGNIFICANCE OF ULTRASONICALLY GUIDED PUNCTURE OF CARCINOMA OF THE GALLBLADDER}

\section{Yoshiji WATANABE, Sadao UEMATSU, Munemasa RYU, Takao FURUKAWA, Toshiyuki KIKUCHI, Masahiko OZAKI, Yoshio KOIDE, Michio ODAKA and Hiroshi SATO}

Second Department of Surgery, School of Medicine, Chiba University

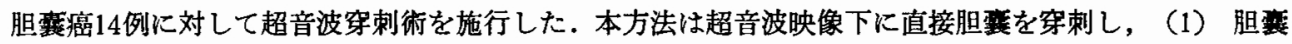

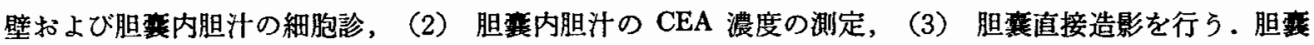
癌14例中細胞診にて13例に悪性細胞を認め, 胆衰内胆汁 CEA 值ば 5 例に測定し平均 $44.0 \mathrm{ng} / \mathrm{ml}$ で胆衰結 石症と比較して有意に高値を示し, 胆谼值接造影では胆衰周辺への癌腫の浸潤状態の適確な把握が可能で あった。

超音波穿刺術は比較的安全な検查法で胆囊癌の早期発見，胆石症との鑑別に非常に有効で今後発展すべ き検查法である。
\end{abstract}

索引用語：胆毫癌，超音波診断，超音波穿刺術，CEA，吸引紐胞診

はじめに

近年肝胆膵疾患に対する診断は超音波検査及び CT ス キャン等の画像診断の飛躍的な発展により目覚しい向上 が認められる.とくに胆整疾患に対しては非常に有力で 胆襄造影陰性例において超音波検查を施行することによ り胆石症と胆襄癌の鑑別及び早期の胆衰癌の診断が比較 的容易に行えるようになり胆㐮癌の診断率および切除率 の向上が認められるよらになってきた。

今回は胆襄疾患に対して超音波画像診断に加えて超音 波誘導下の胆震穿刺術を施行することにより一㬝 (1) 結石合併胆囊癌の診断（2）早期の胆責癌の診断，（3） 胆豪周辺への癌腫の浸潤状態の適確な把握等が可能にな った.

われわれの施行している胆襄穿刺術はりニア式電子ス キャンを用いて胆裏堲および内腔を鮮明に描出し胆整結
石はいらまでもなく腫瘍性病変の診断に応用 しさらに 悪性病変が疑われる場合超音波誘導下に胆襄を直接穿刺 し，（1）胆雍壁および胆雍内胆汁の細胞診，（2）胆 襄内胆汁の CEA (Carcinoembryonic Antigen) 浱度の 測定，（3）䏣凭直接造影等を行う．造影の際胆管との 交通が認められない場合はさらに超音波誘導下に胆管穿 刺を行い，胆衰胆管同時摤み打ち造影を合わせ施行して いる.

胆囊癌に対する超音波穿刺術は比較的安全かつ確実に でき, 早期の胆衰癌発見の期待预よび䏣襄周辺への癌 腫の浸潤状態の把握などが得られる有意義な診断法であ り, 本法の手技, 診断成績, 意義などについて若干の考 察を加えて検討した。

\section{I 施行方法}

超音波診断装置はリニア式電子スキャン（東芝 SAL 
10A 20A), 探触子は通常の診断用探触子又は大藤ら”の 開発した穿刺用探触子を用いる. 穿刺針 $22 \sim 23 G$ PTC 針, その他吸引用ピストン, 注射筒 (Disposable $10 \mathrm{ml}$, $20 \mathrm{ml}$ ) スライドグラス，標本固定用 $100 \%$ アルコールを 用いる.

検查当日朝絶とし早朝に高圧浣腸を施行, 前投薬 と してペンタゾシン 15〜 30mg を検查施行前30分前に筋注 し, 検查後は止血剤, 抗生物質を投与し半日安静䋓食す る.

手技としては患者を仰臥位として超音波映像下に胆裏 及び周辺, 肝内胆管門脈の状態を確認し, 前日ガス隇菌 にて消毒した診断用探触子を用いて右肋間より経皮経肝

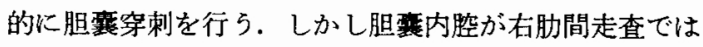
明確に描出できないるのは右前胸部より穿刺用探触子を 用いて経肝的に穿刺する。まず胆裏壁の不規則な肥厚及 び隆起性病変を認めればその部の陰圧吸引細胞診を穿刺 部位を变えて $4 \sim 5$ 力所穿刺吸引する. 次に内腔が明ら かなるのは穿刺針を内腔に刺入し胆汁をできるだけ吸引 乙胆汁の細胞診, CEA, 胆汁内の好気性及び嫌気性菌等 の検査を施行する，最後に60\%ウログラフィンを注入し 胆蘘直接造影を施行する. 造影の際, 胆亯管が閉塞し 胆管との交通が認められない場合, さらに超音波誘導下 に払張した肝内胆管に経皮経肝的に穿刺し胆衰胆管同時
挾み打ち造影を施行する.

\section{II 梌查対象}

現在までに超音波映像下に胆裹穿刺を施行した症例は 胆票癌14例, 胆雍結石症28例と胆裹疾患が多いがその他 ERCP を施行するも胆管拌管がでさなかった膵癌 8 例膵 炎 4 例その他の肝胆膵疾患 7 例の計60例である.

胆襄穿刺術の適応は胆露癌および胆襄癌の疑われる 症例には絶対的適応である. 胆裏結石症の場合, ERCP

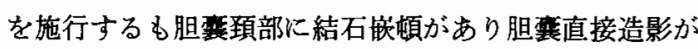
得られない症例も結石合併胆衰癌を考虑して絶対的適応 と考える. その他 ERCP にて胆管择管のできなかった

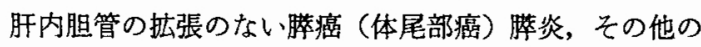
肝胆膵疾患は相対的適応である.

代表的な症例を供覧すると図1（左）は ERCPにて 胆襄が陰性であり胆衰穿刺にて矢印の部の胆裹軠部に小 指頭大の結石の嵌頓を認める.

図1（中）は滕体部癌で肝内胆管の拡張は全く認め ず，胆囊穿刺にて初めて胆道系が鮮明に造影され，矢 印の部に癌腫による軽度のしめつけ像を認める. 図 1

（右）は胆霟癌で体部から頝部にかけて矢印の部に全周 性の陰影欠損像を認める.

\section{III 模查成梳}

現在までに超音波穿刺術を施行し，手術および剖検に

\section{図1 超音波誘導下胆囊造影（疾患別）}

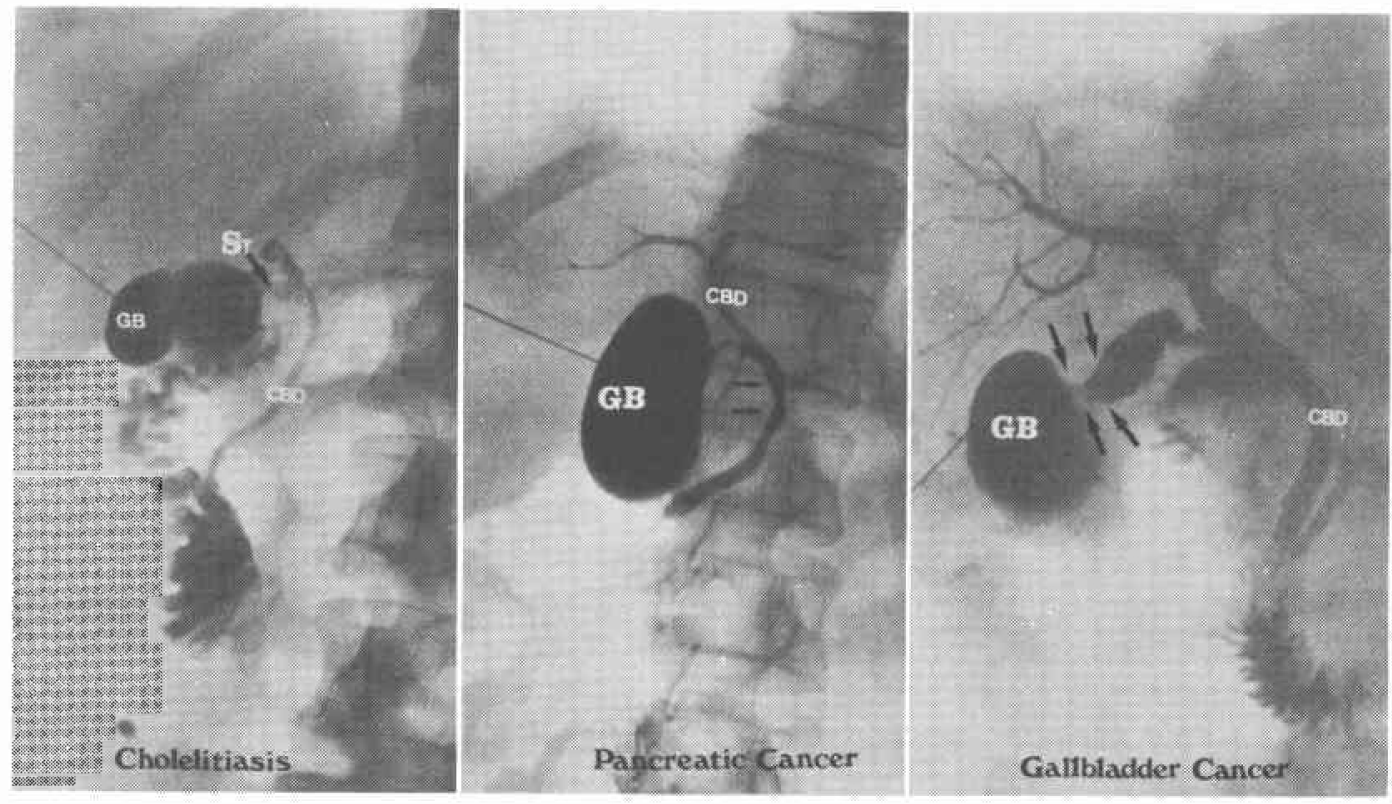




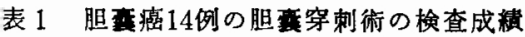

$$
\text { 干大二外 1978.1 1980.6 }
$$

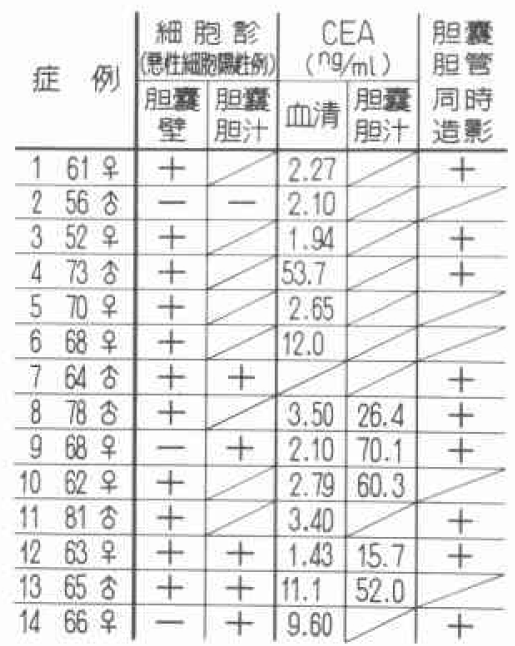

表 2 胆重胆计（CEA 謴度疾患別）

干大二外 $1979.11 \sim 980.6$

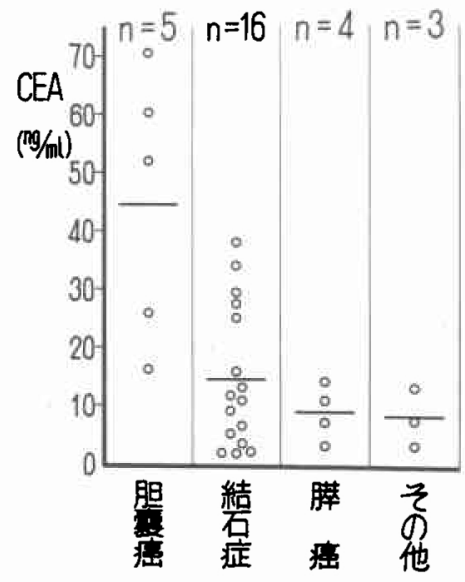

て確認された胆衰癌14例の検查成績は表 1 の如くで吸引

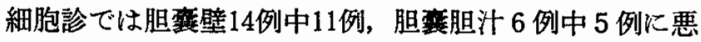
性細胞を認めた. No. 2 の 1 例のみが胆衰壁および胆衰 胆汁とひに細胞診にて悪性細胞を認めず，全体では14例 中13例に执いて術前に胆鸾癌の診断が行われ，診断率 13/14（92.9\%) と非常に高率であった. 表 2 胆咅内胆汁 CEA 濃度は 5 例に測定され最高 $70.1 \mathrm{ng} / \mathrm{ml}$ 最低 $15.7 \mathrm{ng} /$ $\mathrm{ml}$ で平均 $44.9 \mathrm{ng} / \mathrm{ml}$ と高值を示した. 胆表胆管同時造 影は 9 例に施行され胆囊周辺への癌腫の浸潤状態の把握 に非常に有意義で手術術式の決定の 重要な情報を与え た.
胆菱穿刺術の䟢，採取した胆亳内胆汁 CEA 濃度を胆

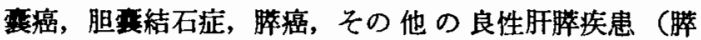
炎, 肝炎, 総胆管抎張症) 等に分けて疾患別に比較検討 する（表2）。CEA 䈨度は Sandwich 法で行なった，胆 漖結石症16例では最高 $37.7 \mathrm{ng} / \mathrm{ml}$ 最低 $1.7 \mathrm{ng} / \mathrm{ml}$ で平均 $14.5 \mathrm{ng} / \mathrm{ml}$ であり, CEA 濃度が $10 \mathrm{ng} / \mathrm{ml}$ 以上を示する のは胆荎炎が強度な症例であり, 更に $20 \mathrm{ng} / \mathrm{ml}$ 以上を示 するのは胆荎内に膿性胆汁を認めた，膵癌 4 例では2.9 $\sim 14.3 \mathrm{ng} / \mathrm{ml}$ で平均 $8.8 \mathrm{ng} / \mathrm{ml}$ ，その他の良性肝胆膵疾患 $2.7 \sim 13.0 \mathrm{ng} / \mathrm{ml}$, 平均 $8.3 \mathrm{ng} / \mathrm{ml}$ であった.

胆毫癌 5 例の平均は $44.9 \mathrm{ng} / \mathrm{ml}$ で胆垔結石, 膵癌等と 比較して有意に高値を示し胆囊内胆汁 CEA が $40 \mathrm{ng} / \mathrm{ml}$ 以上を示するのは胆哇癌を強く疑われる.

\section{IV 合併店}

右肋間走查にて胆童穿刺を施行する場合は検查施行後 に穿刺部の疼痛を訴える例を少数に認める以外には胆汁 漏出, 腹腔内出血等の臨床上問題になる合併症は認めて いない.

胆襄癌の場合胆萃壁の肥厚を伴うむのが多い為右, 前 胸部穿刺にて経肝的でなくても合併症を認めないが胆恶 結石症の一例に前胸部穿刺を行った一例に開腹時軽度の 胆汁漏出を認めた症例があった為胆䒧癌以外は原則とし て右肋間走查にて胆衰穿刺を行う事にしている.

\section{$\mathbf{V}$ 应例}

超音波穿刺術が非常に有効であった典型的な胆暴癌の 症例を供覧する。

1. 患者 山○辰 $\bigcirc$ 助 78 歳, 男性 (No. 8)

昭和54年 9 月初句, 眼球結膜の黄染に気付き近医を受 診し, 閉塞性黄疸の診断にて当科紹介される.

超音波断層像 (図 2 A). 胆䧶体部に 拇指頭大 $の$ 結石

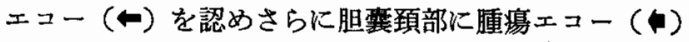
を認める.

胆票胆管像（図 2 B)，胆襄胆管同時造影で，胆管は 総肝管で閉塞され，肝内胆管の強度の拡張を認める. 胆 襄は頙部で閉塞され，体部に円形の結石陰影と体部から 頝部にかけて腫瘤陰影を認める.

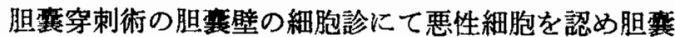
内胆汁 CEA は26.4ng/ml である.

開腹時腫瘍は胆雍体部から頝部にかけて鶚卵大で総肝 管に浸潤していた. 扗大胆摘術兼胆管切除術を施行し， 術後経過良好にて術後 1 力月退院し，現在外来通院にて 経過観察中である.

切除標本では体部に $2.3 \times 1.5 \mathrm{~cm}$ 隆起性病変, 頝部に 
図 2 超音波断層像（A）胆荼胆管同時造影像（B）（症例 1 ）超音波像では胆䟺体部に結石ェコー

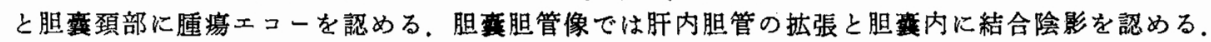

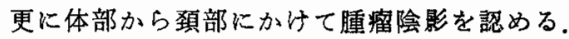
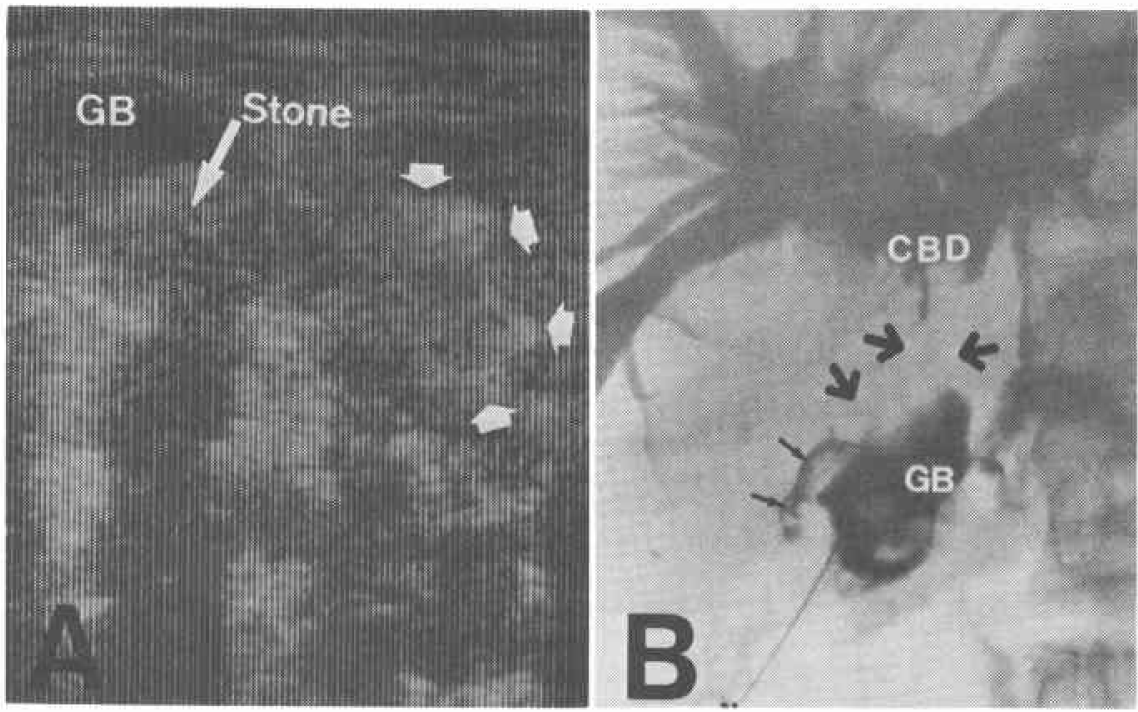

図 3 超音波断層像（症例 2 ）胆萁内に突出する腫 㿟エコーを認める。

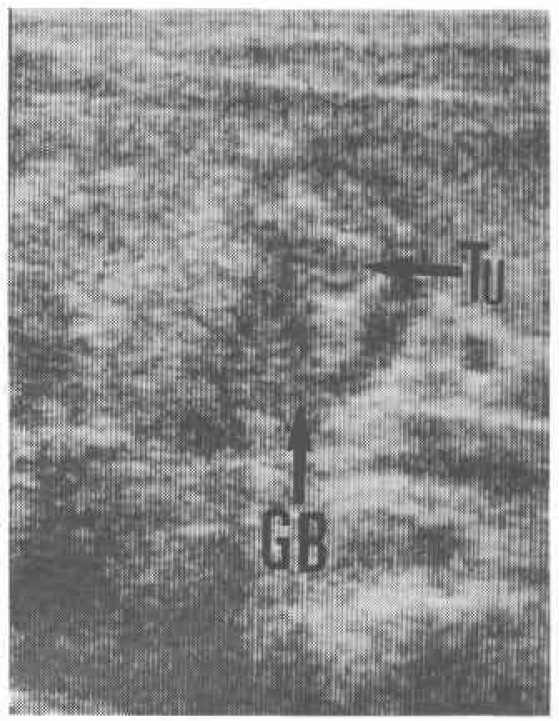

む $2 \times 4 \mathrm{~cm}$ の隆起性病変を認め連続性に総肝管に浸潤し ている. 組織像は高分化型乳頭状腺癌で総肝管及び肝内 直接浸潤を認めた。

次に胆襄壁および胆㪯胆汁の細胞診にて悪性細胞を認 めず診断に苦慮した症例を供覧する.

2. 患者 飯○保 $\bigcirc 56$ 歳, 男性 (No. 2)
昭和54年 3 月中旬右季肋部痛および背部痛出現し，4 月下旬千大第一内科を受診し諸検査を 施行し 胆裟腫瘍 （悪性化の疑い）にて当科紹介される.

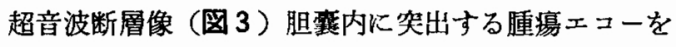
認める (

胆襄像（四 4) 底部から体部にかけて拇指頭大の腫瘤 陰影を認める(๘).

胆变穿刺術の胆汁採取の際, 粘液様物質が吸引された 事と超音波および胆衰造影所見より胆鸾癌と診断.

開腹時胆至内に限局性の拇指頭大の隀瘤を触知するも 肝内直接浸潤および転移を思わせるリンパ節は触知せ ず. 根治手術として扗大肝右葉切除術を施行した。

切除標本 (図 5 ), 胆襄壁底部より内腔へ突出する 1.8 $\times 1.5 \times 2.0 \mathrm{~cm}$ の腫瘍表面に茶褐色の粘液様物質の付着 を認めた. 組織像は高分化型の乳頭状腺癌で深達度は serosaを越えていない.リンパ節転移も全く認めなかっ た.

胆簧結石症を合併したため胆震癌の診断に苦慮したが 䏣雚内胆汁 CEA 值が高值を示し, 胆襄癌の診断の重要 な指針となった症例を供覧する。

3. 患者 上○ア○，68歳，女性 (No. 9)

昭和54年 9 月中旬右季肋部仙痛発作出現. 近医を受診 し治療を受けるも症状改善せず，11月千大第一内科を受 診. DIC にて胆谼造影されず, 諸検査にて胆襄結石症 
図 4 直接胆罊造影（症例 2 ）胆转内に尰瘤陰影を 認める.

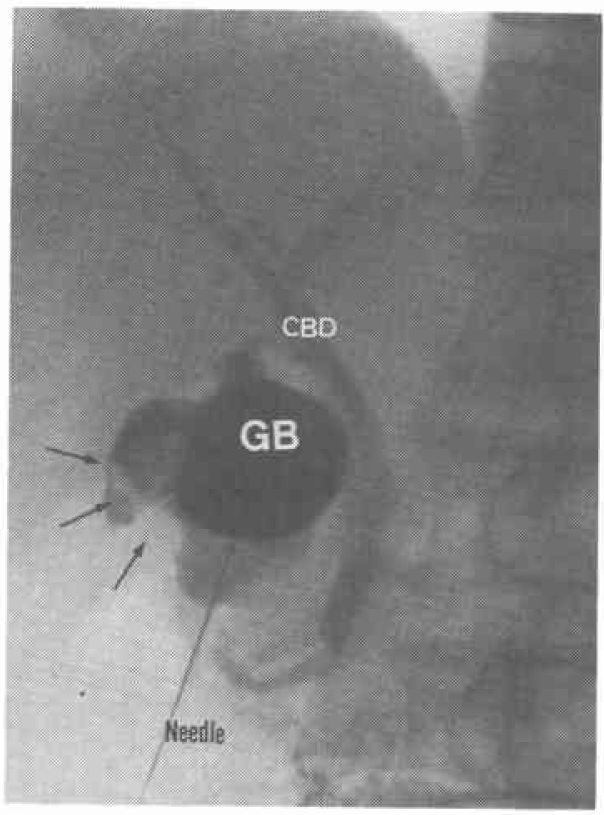

の診断にて当科紹介される.

超音波断層像 (図6)，右胁間走査および 右肋骨弓下 走查ともに胆襄内に数個の結石ェコーと音響陰影を認め るのみで胆囊壁の不規則な肥厚および隆起性病変等は全
図 5 切除標本（症例 2 ）胆患底部に内空へ突出す る腫湯を認める。

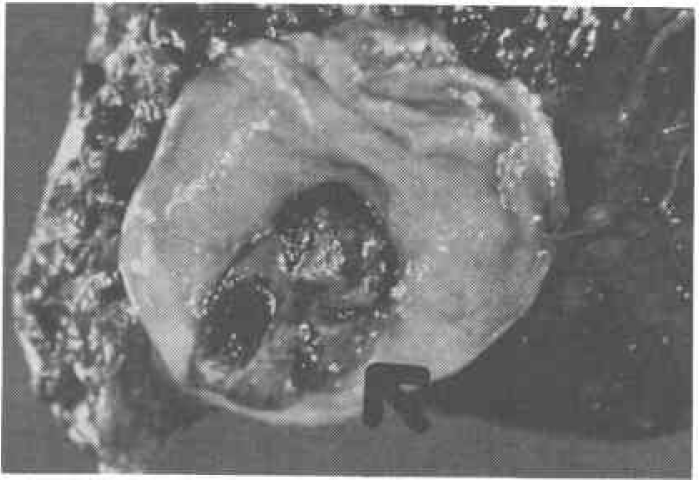

く認めない。胆雜穿刺術を施行し胆衰内胆汁の細胞診で は悪性細胞を認めなかったが CEA 值は70.1ng/ml と高 値を示した。

胆変胆管像 (図 7)，胆辢胆管同時造影で䏣管像では 肝内䏣管に軽度の払張を認める以外異常所見はない，胆

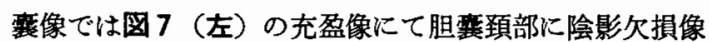
を認め (๘), 右の二重造影にて胆変内に数個の 結石陰

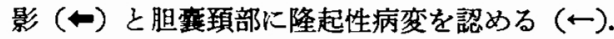

再度胆豊穿刺術を施行するに胆紊胆汁の細胞診にて初 めて悪性細胞を認め (図8), 結石合併胆高癌の診断が できた.

図 6 超音波断㬝像（症例 3 ）右胁骨弓下走査（A）右肋間走查（B）胆露内に数コの結石 エコーを認める.
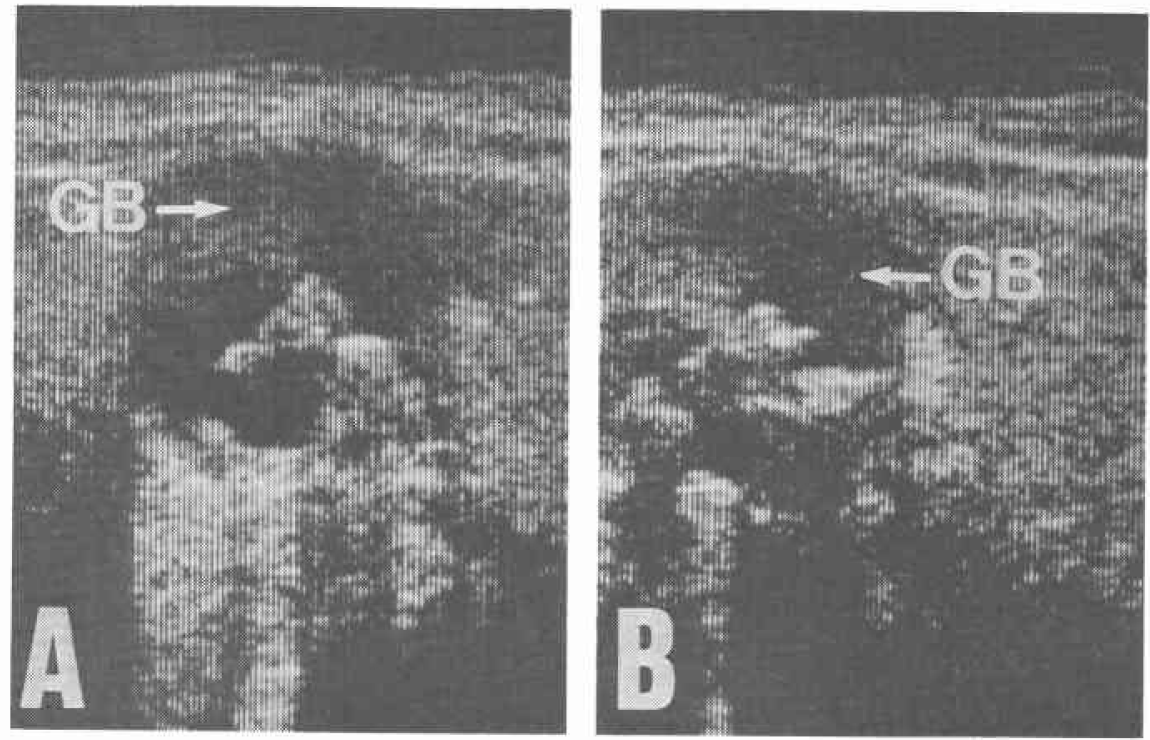


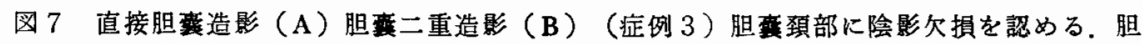
尧二重造影にて結石院影々頚部に隆起性病変を認める。

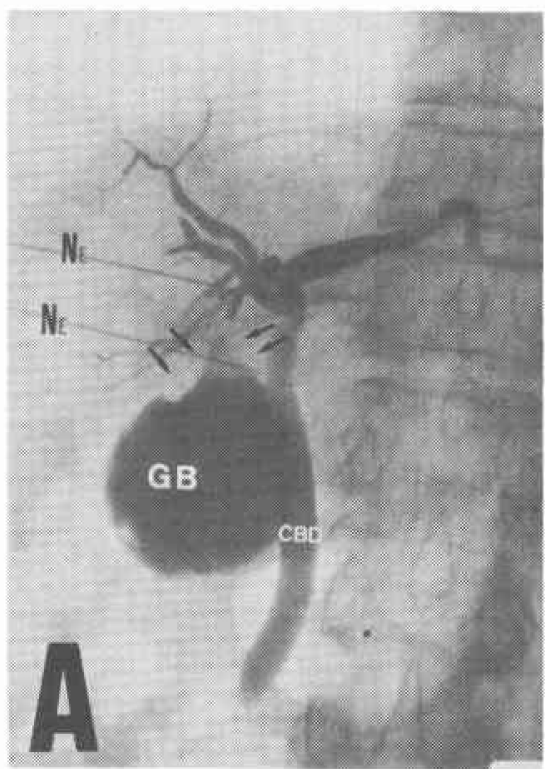

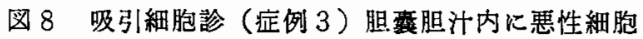
を認める。

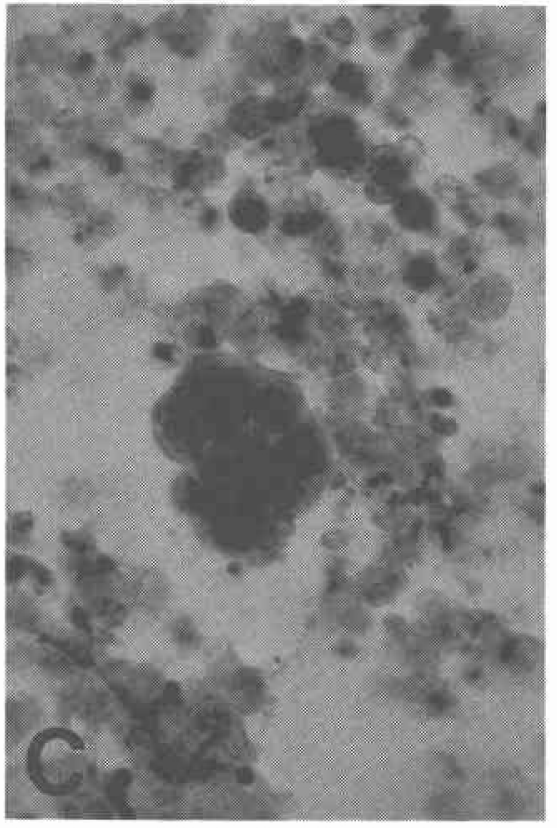

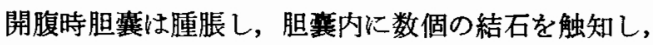
また胆烡額部から胆襄管にかけて硬結を認めた，胆摘廉 胆管切除術を施行した。

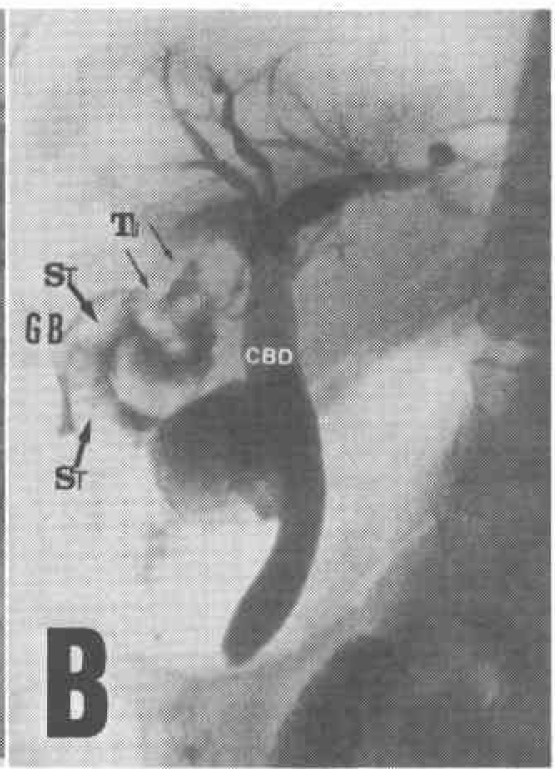

図 9 切除標本（症例 3 ）胆雃頝部に軽度の隆起性 病変を認める。

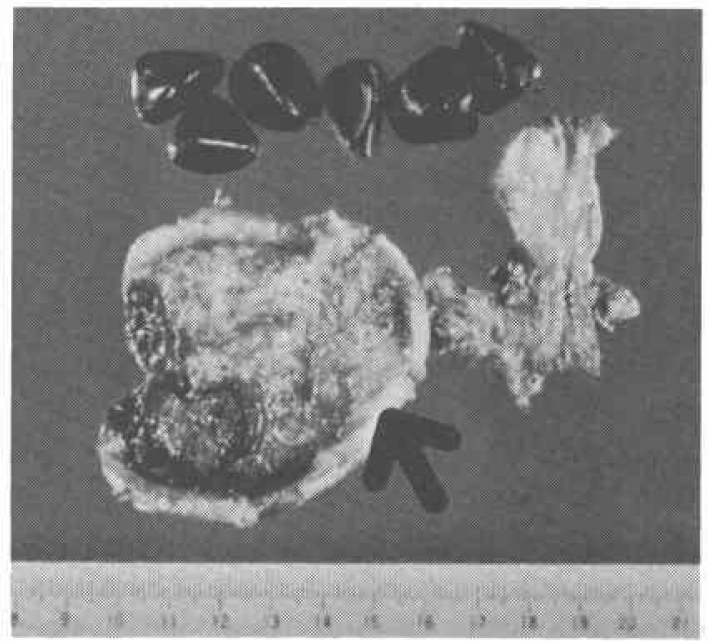

切除標本 (図9), 胆囊頝部に軽度の隆起性病変を認 める (↔). 組織像は高分化型の腺管腺癌で深達度は胆 裹頚部では Serosa まで，胆衰管にて Serosaを越えて 周囲の脂肪組織に浸潤していた。 No. 13のリンパ節は13 個中 8 個に転移を認めたが No. 7, 8 にて転移を認めな かった。 


\section{考雲}

鮮明な胆管像及び胆僎像を得る直接胆道造影法の歴

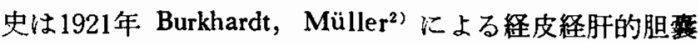
穿刺による造影が最初であり，その後1937年 Huard と Do-Xuran-Hop ${ }^{3)}$ による経皮的に肝内胆管を穿刺する 方 法が行われたが盲目的な穿刺の為穿刺率が低くまた胆汁 漏出，腹腔内出血等の合併症が多いために一般的に普及 しなかった。

1952年 Carter, Saypol ${ }^{4}$ により経皮的経肝穿刺法が比 較的安全に施行出来る事が報告されて以後注目されるよ らになり1960年頃より一般的に普及するようになった。 さらに Arner ${ }^{5}$ らによりX線透視下に胆管を穿刺する方 法が確立され穿刺率の向上と合併症の減少が認められ た.

本邦では窝田ら ${ }^{6)}$ は胆管系をX線解剖学的に詳紐に研 究し安全かつ確実な経皮経肝胆道造影法を確立して以来 一般的行われるようになり，それ以後佐藤 ${ }^{7}$, 大藤 ${ }^{9}$, 穴沢 ${ }^{9)}$ の報告が続き胆脺疾患に対して直接胆道造影法は 不可久の検査法となりルーチンに広く施行されるよらに なった。

最近では解像力の優れた超音波装直の開発によって鮮 明な胆管及び胆襄像が得られるようになってから超音波 映像下の胆管および胆襄穿刺の報告が認められるように なった(0) 13).

土屋ら ${ }^{10)}$ の報告では超音波映像下 PTC を施行するよ らになってからX線透視下 PTC と比較して穿刺回数の 減少や他臓器穿刺の回避ができ, 確実性と安全性におい て超音波映像下 PTC が優れていると述べている.ささら にその穿刺の適応としては肝内結石症, 肝門部胆管癌 などの肝内限局性病変や胆道X線造影で胆敦像が得られ ない胆整造影陰性病変などの病変部の選択的穿刺が必要 となる疾患が良い適応に挙でいる，われわれの超音波映 像下胆襄穿刺の適応として（1）胆衰癌および胆桽癌疑 診，（2）胆霊頝部結石嵌頓，炎症等による胆霍造影陰 性病変は絶対的適応であり，（3） ERCP にて胆管插管 のできない肝内胆管の㹡張のない膵癌, 膵炎, 総胆管払 張症の肝胆膵疾患なども相対的適応である.

胆檋癌においいて，とくに胆襄預部にて閉塞されている 症例に対する胆管胆襄同時挾及打ち造影は胆豊周辺の肝 内胆管および総胆管への癌腫の浸潤状態を適確に把握で き, 胆管切除, 肝右葉切除等の付加手術を決定する重要 な指針となる。

超音波検査が飛躍的に発展する前の胆裴癌の診断率は
欧米では $\mathrm{Lam}^{14}(1950) 34$ 例中 4 例(11.8\%), Sawyer ${ }^{15)}$ （1956）27例中 2 例 $(7.4 \%)$, Klein ${ }^{16)}$ (1972) 28例中 4 例 (14.3\%), Beltz ${ }^{17)}$ (1974) 117例中l1例 (9.4\%), Piehler $^{18)}$ (1977) 48例中 7 例 $(14.6 \%)$ と非常に低率で あった. 我が国でも阿部 ${ }^{19}$ (1973)42例中12例（28.6\%） 永川 ${ }^{20)}$ (1976) 66例中22例 $(33.3 \%)$, 野呂 ${ }^{21)}$ (1976) 41 例中 9 例 $(22.0 \%)$, 土屋 ${ }^{22)}$ (1976) 切除例15例中 4 例 （26.7\%）と欧米に比較すれば若干診断率は高いが全体 では術前診断率は30\%前後と非常に低率であった。

術前診断率が低い理由として癌腫が胆荎頚部を閉塞さ せる症例が多く，IVC，PTC， ERCP では胆裹造影陰性 となり胆変に関する情報が与学れず血管造影や RIscan 等にて診断を行っていた事と結石合併胆変癌が多いため に結石に癌腫が隠されてしまう事の 2 点が大きな理由 と考えられる. しかし超音波険査を行う事に上り胆襄 壁および内腔を鮮明に描出できるようになってから， Hsu.Chong Yeh $^{23)}$ (1979) 13例中11例 (84.6\%), 渡辺 ${ }^{24)}$ （1980）19例中18例（94.7\%）と飛躍的に診断率の向上 が認められるようになった。

われわれの検討でも超音波断層像のみ診断率は 1 例の 疑診を含めて14例中13例 $(92.9 \%)$ と高率であった。診 断できなかった 1 例は結石合併胆垩癌で超音波穿刺術を 施行することにより胆顀胆汁の細胞診にて悪性細胞を認 めさらに胆汁内 CEA が非常に高値を示し, 胆栾癌の診 断が可能であった，結石合併胆衰癌の場合，超音波断層 像のみでは結石エューに腫湟エコーが隐される事がある ので時に部断が困難な事がある. また胆㝨内腔へ突出す る腫瘍を超音波断層像にて腫瘍エコーとして認めても 良, 悪性の鑑別揨断は困難であり, 超音波穿刺術による 細胞診等が必要である.

胆蘘癌の術前診断率の向上に伴い切除率の向上も認め られるようになってきた. 1975年の日本消化器外科学 会ンンポジウム“胆襄癌の診断と治療の司会者東北大佐 藤 ${ }^{25)}$ の全国主要病院アンケートによれば60施設1,433例 中手術された1,381例中姑息切除を含めて切除されたも のは565例 (40.9\%) と低率であったが超音波検査の進 歩により比較的早期の胆亚癌が発見されるようになり切 除率の向上を認める. われわれの施設でる超音波検查導 入前の 1977 年までの切除率は24例中 6 例 $25.0 \%$ と非常に 低率であったが導入以後は14例中11例 $(78.6 \%)$ と飛翟 的に向上した。

胆震内胆汁 CEA 濃度を胆囊癌と他の肝胆膵疾患と比 較検討した報告はなくわれわれの報告が最初である，胆 
霆癌を含めた胆道癌について血中 CEAを検討した報告 は若干認められるが臨床的に進行した症例が多い為に血 中 CEA が陽性になる率は高く島塚 ${ }^{26)} 9$ 例中 9 例 $100 \%$, 伊藤 ${ }^{27)} 6$ 例中 4 例 $66.7 \%$, 神前ら ${ }^{28)}$ は 43 例中 26 例 $61 \%$ であった。 われわれの胆襄癌12例中 8 例 $(75.0 \%)$ が $2.5 \mathrm{ng} / \mathrm{ml}$ 以上を示し, 陽性例には比較的進行した症例 が多く, 肝転移や骨転移を伴ったものは $10 \mathrm{ng} / \mathrm{ml}$ 以上を 示すものが多かったが逆に肝転移を垫めても2.5ng/ml以 下のものもあり, 血中 CEA 濃度そのものの診断的価值 は低く他の検查と組み合わせることにより補助的䛦断と しての価值は認められる。

伊藤ら ${ }^{27)}$ は，胆石症の術前の血清 CEA を測定し胆变 癌との鑑別に有用となるかどらかを検討した結果 $2.5 \mathrm{ng} /$ $\mathrm{ml}$ 以上を陽性とすると胆衰癌 $66.7 \%$, 胆軎結石症 8.7 $\%$, 総胆管結石症 $17.4 \%$ と胆震癌が有意に高値を示した が早期診断には熬がらなかったと述べている．また胆汁 感染と胆汁内 CEA 値の検討によると胆汁感染のあった 6 例中 4 例の CEA は $5 \mathrm{ng} / \mathrm{ml}$ 以上であったが胆汁感染 のない3例の CEA は低值であったと述べている.

われわれの胆豪穿刺術にて採取した胆汗内 CEA 濃度 を検討した結果癌腫が有意に胆襄結石症等の疾患と比較 し高値を示した事は，胆䧶癌の診断に際して特に結石合 併胆襄癌に有效であり, 今後は胆汁内 CEA 濃度と胆栾 癌の進行程度との関連について症例を重ね検討するつる りである. 現在膵癌特に膵頭部癌の総胆管内胆汁 CEA 値も検討しているが胆管浸潤を示寸るのに有意に高值を 示すあのが多い.

\section{おわりに}

超音波穿刺術を胆霟癌 14 例に施行し全例術前に胆恶癌 の診断を得て,さらに胆霊周辺への浸潤状態を把握でき た. 胆䧶内胆汁 CEA 值は癌において結石症と比較して 有意に高値を示した. 本法は胆慗疾患ことに胆表癌の早 期発見, 胆石症との鑑別に今後発展すべき有力な検査法 である。

本論文の要旨は1980年 7 月第16回日本消化器外科学会 総会にて発表した。

\section{文献}

1) 大藤正雄他：リニア電子走查形超音波診断用装 置における臟器穿刺利用探触子とその臨床応 用. 日超医講演集, 33:271，1978.

2) Burkhardt, H. and Müller, H.: Versuche über die punktion der gallenblase und ihre Röntgendarstellung. Deutscher. Zeistschrift fur Chirugie: 161: 168-197, 1921.

3) Huard, P. and Doxuran Hop.: La punction transhepatique des canaux biliares. Bull. Soc. Med. Cli. Indoch: 15: $1090,1937$.

4) Carter, R.F. and Saypol, M.: Trans- abdominal cholangiography. J.A.M.A., 148: 253, 1952.

5) Arner, O., et al.: Percutaneous transhepatic cholangiography-puncture of dilated and nondilated bile duct under Röntzentelevision control. Surg., 52: $561-571,1962$.

6) 窪田博吉他：経皮的胆の5胆管造影法. 外科治 療, 13: 127-139, 1965.

7) 佐藤寿雄他: 経皮的経肝性胆道造影法. 臨床外 科, $24: 303-315,1969$.

8) 大藤正雄他：経皮的胆管穿刺造影法一内科的応 用について一。 日本臨休, 29：2748一 2804, 1969.

9）穴沢雄作他：経皮胆管造影の臨床的意義, 外科 診療, 13:1309-1918, 1971 .

10）土屋幸治他：胆道造影（PTC， IVC）に上る勝 癌の診断。内科, 43 ：757-762, 1979.

11) 高田忠敬他: 超音波誘導下 PTC, PTCD の工 夫. 日超医誌, 35：120-121，1979.

12）高田悦雄他：超音波ガイド下経皮経肝胆囊造 影。日超医誌, 35:119, 1979.

13）伊藤徹他：超音波誘導下胆道ドレナージ法. 日超医誌, $35: 121 ， 1979$.

14) Lam, C.R., et al.: The dresent status of carcinoma of the gallbladder. A study of thirtyfour clinical cases. Ann. Surg., 111 : 403-411, 1940.

15) Sawyer, C.P., et al.: Primary carcinoma of the gallbladder. Amer. J. Surg., 91: 99-105, 1956.

16) Klein, J.B., et al.: Primary carcinoma of the gallbladder review of 28 cases. Arch. Surg., 104: 769-772, 1972.

17) Beltz, W.R., et al.: Primary carcinoma of the gallbladder. Ann. Surg., 180: 180-184, 1974.

18) Piehler, J.M., et al.: Primary carcinoma of he gallbladder. Arch. Surg., 112: 26--30, 1977.

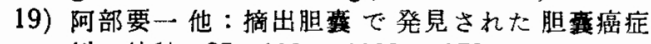
例. 外科, $35: 1084-1089,1973$.

20) 永川宅和他：胆囊癌の診断々治療. 日消外誌, 9: 157-162, 1976.

21）野呂俊夫他：肉眼的進展様式からみた胆䓵癌の 診断と治療についての検討. 日消外誌, 9: $178-185,1976$.

22) 土屋凉一他：胆表癌の外科的治療一七くに 2 期 的拡大根治手術について。 日消外誌, $9: 193-$ 198, 1976.

23) Hsu-Chong Yoh.: Ultrasonography and computed tomography of carcinoma of the gallbladder. Radiology, 133: 167-173, 1979.

24）渡辺栄二他：胆のら癌の超音波断層像につい て。目超医論文集, 36：115-116，1980.

25）佐藤寿雄: 胆の5癌の治療をめぐる 2,3 の問 題点。外科, $38: 378-380,1976$.

26) 島塚莞爾他：ガン訩断への応用 (CEA の基碄 之臨床). 癌と化学療法, $4: 231-244,1977$.

27) 伊藤新一郎他：胆桽癌の診断における血清 CEA の測定の意義と限界。日癌治誌, 14：967一 971, 1979 . 